\title{
Inhibisi Lipase Pankreas secara In Vitro oleh Ekstrak Air dan Etanol Daun Asam Jawa (Tamarindus indica) dan Rimpang Kunci Pepet (Kaempferiae rotundae)
}

\author{
Dyah Iswantini Pradono ${ }^{\left.1,2^{*}\right)}$, Latifah Kosim Darusman ${ }^{1,2)}$, dan Ai Susanti' ${ }^{2)}$ \\ 1) Jurusan Departemen Kimia, Fakultas Matematika dan IImu Pengetahuan Alam, Institut Pertanian Bogor, \\ Jalan Raya Pajajaran, Bogor 16144 \\ 2)Departemen Kimia, Fakultas Matematika dan Ilmu Pengetahuan Alam, Institut Pertanian Bogor, \\ Jalan Agatis Kampus IPB Darmaga, Bogor 16680
}

Diterima 24-11-2009 Disetujui 12-10-2010

\begin{abstract}
Tamarind and kunci pepet has been used traditionally as herbal medicine to reduce body weight or used as antiobesity. But the mechanism in vitro of this herbal in reducing body weight has not been known yet. The objective of this research is to evaluate these herbal as antiobesity by their water and ethanol extracts capability in inhibiting pancreatic lipase activity in vitro at $\mathrm{pH} 8$, incubation time 45 minutes, and temperature $40^{\circ} \mathrm{C}$. Pancreatic lipase used in this research was human pancreatic lipase with concentration of $1.4 \times 10^{-5} \mu \mathrm{g} / \mu \mathrm{l}$ and the substrate was sesame oil with concentration of $16.2 \mu \mathrm{g} / \mu \mathrm{l}$. The water and ethanol extracts of tamarind leaves contained alkaloids, flavonoids, saponins, steroids, and tannins. Water extract of kunci pepet contained alkaloids, flavonoids, saponins, and tannins, while ethanol extract contained alkaloids, flavonoids, saponins, and triterpenoids. The results of tamarind leaves extracts showed that ethanol extract in concentration of $150 \mathrm{ppm}$ had the highest inhibitory effect, with the value of $49.0 \%$. Water extract of kunci pepet at concentration of $200 \mathrm{ppm}$ had the highest

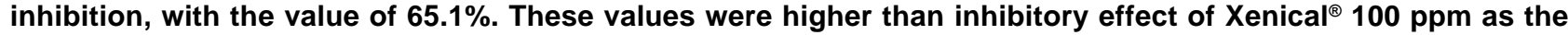
positive control, with the inhibition value of $10.6 \%$.
\end{abstract}

Keywords: antiobesity, asam jawa (Tamarindus indica), inhibition, in vitro pancreatic lipase activity, kunci pepet (Kaempferiae rotunda)

\section{PENDAHULUAN}

Akhir-akhir ini, kecenderungan manusia untuk kembali ke alam semakin meningkat, termasuk penggunaan obat-obat pelangsing yang berasal dari tumbuhan. Kecenderungan ini disebabkan oleh obat pelangsing alami dari tumbuhan dirasakan mempunyai efek samping yang lebih rendah dibandingkan dengan obat-obat pelangsing modern.

Keanekaragaman tumbuhan obat pelangsing di Indonesia merupakan sumber metabolit sekunder yang dapat digunakan sebagai bahan baku dalam pembuatan obat pelangsing. Tumbuhan obat pelangsing asli Indonesia, pada kenyataannya sampai saat ini masih banyak digunakan oleh masyarakat. Pengetahuan ini telah diwariskan secara turun-temurun berdasarkan pada adat kebiasaan semata. Dalam rangka inilah diperlukan penelitian sehingga pengobatan secara tradisional dapat dipertanggungjawabkan penggunaannya, termasuk untuk antiobesitas.

\footnotetext{
*Telp: +6281219818810

Email: dyahprado@yahoo.co.id
}

Obesitas adalah suatu penyakit multi-faktorial sebagai akibat dari energi yang masuk ke dalam tubuh lebih banyak daripada energi yang dikeluarkan oleh tubuh. Obesitas bagi sebagian orang sangat mengganggu, baik dalam hal penampilan maupun kesehatan. Penyakit-penyakit yang diakibatkan oleh obesitas adalah diabetes melitus tipe II, hipertensi, radang sendi, dan penyakit jantung pembuluh darah yang dapat menyebabkan kematian (Rahardjo et al., 2005). Oleh sebab itu, banyak orang melakukan berbagai cara untuk menurunkan bobot badannya. Lemak yang terdapat di dalam tubuh dihidrolisis pada jaringan pankreas. Apabila aktivitas lipase pankreas meningkat, maka akan meningkatkan penyerapan monogliserida dan asam lemak yang berpengaruh pada obesitas (Joshita et al., 2000). Hal inilah yang akan menimbulkan penimbunan lemak dalam tubuh. Oleh karena itu, aktivitas lipase pankreas harus dihambat supaya penimbunan lemak tidak terjadi. 
Lipase pankreas merupakan enzim yang terdapat dalam tubuh manusia, yang terutama berperan dalam penguraian lipid untuk mengabsorpsi asam lemak (Shin et al., 2003). Cara-cara yang dapat digunakan untuk menurunkan bobot badan, yaitu olahraga yang teratur, mengkonsumsi makanan yang rendah kalori, dan mengkonsumsi obat-obat pelangsing yang beredar di pasaran. Cara lain yang dapat digunakan untuk menurunkan bobot badan adalah mengkonsumsi obat yang dapat menghambat nafsu makan (Amfetamin) dan menghambat absorpsi lemak melalui penghambatan aktivitas lipase pankreas (Orlistat). Bahkan, sebagian kalangan wanita banyak yang menggunakan jamu untuk mengatasi masalah kegemukannya, seperti menggunakan jamu Galian Singset, Merit, Ideal, dan sebagainya.

Tanaman obat yang mampu menurunkan bobot badan melalui mekanisme tersebut, di antaranya adalah daun jati belanda, rimpang bangle, malabar tamarind (Garcinia cambogia), mangrove jenis Rhizopora mucronata, daun asam jawa, rimpang kunci pepet, temu ireng, dan kemuning (Digest, 2006). Malabar tamarind, misalnya, berkhasiat menekan rasa lapar dan meningkatkan rasa kenyang (Digest, 2006), sedangkan tanin yang banyak terkandung di bagian daun jati belanda dapat mengurangi penyerapan makanan dengan cara mengendapkan mukosa usus yang ada dalam permukaan usus (Hendri, 2006). Penelitian mengenai rimpang bangle menunjukkan bahwa ekstrak metanol, flavonoid, dan tanin dapat menghambat Ekstrak teh oolong, ekstrak herba Cassia nomame, dan rimpang jahe (Han et al., 1999; Yamamoto et al., 2000; Han et al., 2005), serta rimpang bangle dapat menghambat aktivitas lipase secara in vitro (Iswantini et al., 2003; Febriany, 2004; Wirakusumah, 2005; Silitonga, 2008).

Penelitian lain menunjukkan bahwa senyawa aktif yang berpotensi sebagai antiobesitas dalam menghambat aktivitas lipase pankreas adalah saponin yang terdapat pada tanaman Thea sinensis (Han et al., 2001) dan Platycodi radix (Xu et al., 2005), Panax japonicus (Han et al., 2005), tanaman Kochia scoparia (Han et al., 2006), dan buah Acanthopanax senticosus (Li et al., 2007), serta flavonoid dan steroid misalnya pada daun jati belanda (Darusman et al., 2001 \& Iswantini et al., 2003). Oleh karena itu, daun asam jawa yang mengandung flavonoid, saponin, tanin, steroid, dan alkaloid, serta rimpang kunci pepet yang mengandung saponin, polifenol, flavonoid, dan minyak atsiri diharapkan mampu mendukung potensi tersebut.

Berdasarkan penggunaan di masyarakat, daun asam jawa dan rimpang kunci pepet yang belum diketahui senyawa aktifnya ternyata berpotensi sebagai pelangsing. Belum terdapat paten yang memuat informasi mengenai antiobesitas berbasis daun asam jawa maupun rimpang kunci pepet sehingga penelitian ini perlu dilakukan. Penelitian ini berpotensi menghasilkan suatu formula yang dapat dipatenkan.

Penelitian ini bertujuan mengevaluasi daya inhibisi ekstrak air dan ekstrak etanol pada daun asam jawa dan rimpang kunci pepet terhadap aktivitas lipase pankreas secara in vitro dalam potensinya sebagai antiobesitas.

\section{BAHAN DAN METODE}

Lipase pankreas yang digunakan adalah lipase pankreas manusia (Sigma L9780-50 units). Sampel daun asam jawa diperoleh dari Balai Penelitian Tanaman Obat dan Aromatik (Balittro) dan rimpang kunci pepet diperoleh dari Pusat Studi Biofarmaka, Bogor. Pereaksi Natrium dietilditiokarbamat, asam oleat (Sigma), minyak wijen ABC, Xenical ${ }^{\circledR}$ (Roche Pharmaceuticals), dan spektrofotometer UV-Vis U-2800 Hitachi.

Ekstraksi air dan etanol sampel menggunakan simplisia sebanyak $\pm 100 \mathrm{~g}$ dan pelarut yang digunakan masing-masing sebanyak $500 \mathrm{ml}(3 \times 24$ jam) dengan metode maserasi. Uji fitokimia yang dilakukan, yaitu uji alkaloid, flavonoid, saponin, steroid, tanin, triterpenoid berdasarkan metode Harborne 1987.

Uji Toksisitas terhadap Larva Udang (Meyer et al., 1982). Uji toksisitas dengan menentukan nilai $\mathrm{LC}_{50}$ dilakukan untuk menentukan konsentrasi ambang untuk pengujian in vitro artinya uji in vitro akan dilakukan dibawah konsentrasi $\mathrm{LC}_{50}$-nya. Uji ini dilakukan dengan menggunakan telur udang Artemia salina. A. salina yang digunakan untuk uji toksisitas diperoleh dari hasil penetasan dengan menggunakan air laut dengan bantuan aerator untuk memenuhi kadar oksigen yang terlarut.

Uji toksisitas ekstrak dilakukan dengan menggunakan larva udang $\boldsymbol{A}$. salina. Larva udang yang digunakan berumur 48 jam setelah larva udang menetas. Kista $A$. salina sebanyak $\pm 50 \mathrm{mg}$ dimasukkan ke dalam wadah yang berisi air laut yang sudah disaring dan dilengkapi aerator. Kista dibiarkan selama 48 jam di bawah pencahayaan lampu agar 
menetas sempurna. Setelah menetas, larva $A$. salina sebanyak 10 ekor dimasukkan ke dalam vial $2 \mathrm{ml}$, kemudian ditambahkan larutan stok ekstrak dengan konsentrasi 4000 ppm dan ditepatkan volumenya dengan air laut sehingga konsentrasi akhir ekstrak menjadi 0, 10, 100, dan 1000 ppm. Setelah 24 jam, jumlah larva yang mati dihitung. Nilai konsentrasi letal $\left(\mathrm{LC}_{50}\right)$ ditentukan dengan metode analisis probit dengan selang kepercayaan 95\%.

Uji In vitro Ekstrak terhadap Aktivitas Hidrolisis Lipase Pankreas (Han et al., 2005). Metode uji in vitro yang digunakan ini mengacu pada metode yang digunakan oleh Han et al., (2005) dengan beberapa modifikasi, yaitu menggunakan substrat triolein, bufer $\mathrm{N}$-tris-(hidroksimetil)-metil-2-aminaetana-asam sulfat pada $\mathrm{pH} 7$, suhu $37^{\circ} \mathrm{C}$ dengan waktu inkubasi 30 menit, dan larutan pengkompleks warna batokuproin dalam kloroform $0.05 \%(b / v)$. Metode uji in vitro yang digunakan kali ini berbeda dengan metode yang biasa digunakan untuk uji in vitro yang menggunakan lipase pankreas oleh Han et al., (2005).

Metode yang digunakan kali ini lebih sederhana, yaitu dengan menggunakan minyak wijen sebagai substrat dan pereaksi-pereaksi lain yang lebih sederhana. Sebanyak $15 \mu$ substrat dan ekstrak sampel dimasukkan ke dalam tabung reaksi, lalu ditambah dengan $10 \mu \mathrm{l}$ albumin $10 \%$ dan larutan bufer fosfat $\mathrm{pH}$ 8. Setelah itu, $100 \mu \mathrm{l}$ lipase pankreas dimasukkan ke dalam tabung reaksi tersebut dan diinkubasi pada $\mathrm{pH} 8$, suhu optimum $\left(40^{\circ} \mathrm{C}\right)$ selama 45 menit. Setelah mencapai waktu optimum, reaksi dihentikan dengan cara menambahkan $3 \mathrm{ml}$ kloroform. Larutan dalam tabung kemudian dikocok dan disentrifugasi selama 5 menit. Sebanyak $1 \mathrm{ml}$ lapisan kloroform, kemudian diambil dan ditambahkan $4 \mathrm{ml}$ kloroform-heptana (1:1), serta dikocok hingga homogen. Setelah itu, larutan ditambahkan 2,5 ml pereaksi tembaga, dikocok 3 menit hingga homogen, dan disentrifugasi kembali selama 10 menit. Lapisan kloroform diambil sebanyak $3 \mathrm{ml}$ dan ditambahkan 0,25 ml larutan Na-dietilditiokarbamat hingga berwarna kuning. Larutan diukur serapannya dengan menggunakan spektrofotometer UV-Vis pada panjang gelombang $435 \mathrm{~nm}$. Nilai yang diperoleh, kemudian dikonversi dengan perhitungan sehingga diperoleh nilai aktivitas lipase pankreas. Aktivitas lipase pankreas dinyatakan dalam $\mu \mathrm{mol}$ asam oleat/l.menit. kontrol negatif dilakukan tanpa penambahan ekstrak, sedangkan untuk kontrol positif dilakukan dengan mengganti ekstrak dengan Xenical ${ }^{\circledR}$.

Penentuan Kadar Flavonoid Total (Codex 1986 diacu dalam Nobre et al., 2005). Metode ini berdasarkan pada Codex (1986) diacu dalam Nobre et al., (2005). Ekstrak terbaik yang memiliki daya inhibisi terbesar yang setara dengan 200 mg simplisia ditimbang dan dimasukkan ke labu bulat. Sistem hidrolisis berupa $1.0 \mathrm{ml}$ larutan heksametilenatetramina $0.5 \% \mathrm{~b} / \mathrm{v}, 20 \mathrm{ml}$ aseton, dan $2 \mathrm{ml} \mathrm{HCl} 25 \%$ ditambahkan ke dalam labu tersebut. Selanjutnya, ekstrak dihidrolisis dengan pemanasan hingga mendidih selama 30 menit. Campuran hasil hidrolisis disaring menggunakan kapas ke dalam labu takar $100 \mathrm{ml}$, kemudian residunya ditambahkan $20 \mathrm{ml}$ aseton dan dididihkan kembali (dilakukan 2 kali dan filtrat dikumpulkan ke dalam labu takar, lalu ditera dengan aseton). Sebanyak $20 \mathrm{ml}$ filtrat hasil hidrolisis dan $20 \mathrm{ml}$ akuades dimasukkan ke dalam corong pisah, lalu diekstraksi dengan etil asetat (ekstraksi yang pertama dengan $15 \mathrm{ml}$ etil asetat, ekstraksi kedua dan ketiga dengan $10 \mathrm{ml}$ etil asetat). Fraksi etil asetat dikumpulkan dalam labu takar $50 \mathrm{ml}$, kemudian ditera dengan etil asetat.

Pengukuran spektrofotometri. Sebanyak $10 \mathrm{ml}$ larutan fraksi etil asetat dimasukkan ke dalam labu takar $25 \mathrm{ml}$, lalu direaksikan dengan $1 \mathrm{ml}$ larutan $\mathrm{AlCl}_{3}$ $2 \% \mathrm{~b} / \mathrm{v}$ dan ditera dengan larutan asam asetat glasial $5 \% \mathrm{v} / \mathrm{v}$ dalam metanol. Pengukuran larutan dilakukan pada panjang gelombang $370,8 \mathrm{~nm}$. Kurva standar dibuat dengan kuersetin murni dengan konsentrasi $0 ; 0.5 ; 2.5 ; 5 ; 7.5$, dan 10 ppm.

\section{HASIL DAN PEMBAHASAN}

Kadar Air dan Ekstraksi. Kadar air daun asam jawa sebesar 9,2\%, sedangkan kadar air rimpang kunci pepet sebesar $5,5 \%$. Kadar air daun asam jawa dan rimpang kunci pepet yang diperoleh kurang dari $10 \%$ sehingga dapat terhindar dari serangan mikroba selama penyimpanan. Metode ekstraksi yang digunakan dalam penelitian ini, yaitu maserasi dengan air deionisasi dan etanol $70 \%$ sebagai larutan pengekstrak. Metode ini berdasarkan pada penelitian Doughari (2006). Rendemen yang diperoleh dari ekstrak air dan etanol daun asam jawa berturut-turut sebesar 20,5 dan 12,2\%, sedangkan ekstrak air dan etanol rimpang kunci pepet sebesar 19,2 dan 16,7\%. Ekstrak ini selanjutnya diuji kandungan senyawa metabolit sekunder, toksisitasnya terhadap larva udang, daya inhibisi terhadap aktivitas 
lipase pankreas secara in vitro, dan penentuan kadar flavonoid total dari ekstrak terbaik daya inhibisinya.

Uji Toksisitas terhadap Larva Udang. Uji toksisitas larva udang pada penelitian ini dilakukan sebagai uji pendahuluan untuk mengamati potensi bioaktivitas dan toksisitas dari masing-masing sampel sehingga dapat ditentukan konsentrasi ekstrak yang aman untuk pengujian. Jumlah larva udang yang mati akibat pengaruh ekstrak ditunjukkan pada Lampiran 1.

Suatu ekstrak tanaman akan bersifat bioaktif apabila mempunyai nilai LC $_{50}$ kurang dari 1000 ppm (Meyer et al., 1982). Berdasarkan Tabel 1 dapat diketahui bahwa ekstrak air daun asam jawa, ekstrak etanol daun asam jawa dan rimpang kunci pepet berpotensi sebagai senyawa bioaktif dan dapat dijadikan sebagai obat karena menghasilkan LC $_{50}$ kurang dari 1000 ppm sehingga pada konsentrasi yang rendah telah mampu mematikan $50 \%$ populasi larva udang $A$. salina, sedangkan ekstrak air rimpang kunci pepet mempunyai bioaktivitas yang rendah karena untuk mematikan 50\% pupulasi larva udang diperlukan konsentrasi ekstrak di atas 1000 ppm.

Ekstrak yang memiliki potensi bioaktif yang paling tinggi dan bersifat toksik adalah ekstrak etanol daun asam jawa. Hal ini disebabkan oleh ekstrak etanol daun asam jawa memiliki nilai LC $_{50}$ yang paling rendah, yaitu 176.41 ppm yang berarti pada konsentrasi yang kecil ekstrak ini dapat mematikan setengah populasi dari larva udang $A$. salina. Ekstrak yang memiliki potensi bioaktif yang tinggi belum tentu mempunyai daya inhibisi yang tertinggi. Hal ini disebabkan oleh nilai LC $_{50}$ hanya digunakan sebagai batas konsentrasi tertinggi pada penentuan ragam konsentrasi ekstrak dalam uji enzimatik sehingga formulasi obat akan lebih aman jika konsentrasi yang dibuat di bawah $\mathrm{LC}_{50}$.

Uji In vitro Ekstrak terhadap Aktivitas Hidrolisis Lipase Pankreas. Penentuan aktivitas lipase pankreas dilakukan dengan menggunakan asam oleat dengan konsentrasi 4,25 $\mu \mathrm{mol}$ sebagai standar dengan nilai serapan sebesar 0,041. Perlakuan standar dimulai pada tahap penambahan kloroform-heptana (1:1) yang

Tabel 1. Nilai LC $_{50}$ ekstrak air dan ekstrak etanol sampel terhadap

\begin{tabular}{cll}
\multicolumn{1}{c}{ larva $A$. Salina } & & \\
\hline Contoh & Ekstrak & $\mathrm{LC}_{50}(\mathrm{ppm})$ \\
\hline Daun asam jawa & Air & 550,27 \\
& Etanol & 176,41 \\
\multirow{2}{*}{ Rimpang kunci pepet } & Air & 1140,89 \\
& Etanol & 504,43 \\
\hline
\end{tabular}

selanjutnya sama seperti prosedur uji aktivitas hidrolisis lipase pankreas. Substrat yang digunakan dalam uji in vitro lipase pankreas ini adalah minyak wijen. Minyak wijen digunakan sebagai substrat pada penelitian ini karena minyak wijen merupakan trigliserida rantai panjang yang tidak larut dalam air dan merupakan substrat terbaik selain triolein dan trilinolein dalam pengujian in vitro terhadap aktivitas lipase pankreas (Desnuelle \& Savary, 1963). Hasil optimasi lipase pankreas yang dilakukan oleh Martatilofa dan Silitonga (2008) menunjukkan bahwa enzim ini memiliki aktivitas optimum pada $\mathrm{pH} 8$, waktu inkubasi 45 menit, dan suhu $40^{\circ} \mathrm{C}$. Menurut Hadvary et al., (1988), lipase pankreas juga memiliki aktivitas optimum pada $\mathrm{pH} 8$. Konsentrasi lipase pankreas yang digunakan sebesar $1,4 \times 10^{-5} \mathrm{ig} / \mathrm{il}$, konsentrasi substrat yang digunakan sebesar 16.2 ìg/ìl, dan panjang gelombang yang menunjukkan serapan maksimum sebesar $435 \mathrm{~nm}$ sehingga penelitian ini menggunakan kondisi optimum tersebut. Suhu dan pH optimum dari suatu enzim sangat penting untuk diketahui karena pada keadaan tersebut enzim mempunyai stabilitas dan aktivitas yang optimum.

Seluruh ekstrak diuji aktivitas lipase pankreas secara in vitro dengan menggunakan spektrofotometer UV-Vis pada berbagai konsentrasi dalam menghambat aktivitas lipase pankreas dan dihitung daya inhibisinya. Ragam konsentrasi ekstrak yang digunakan adalah 100, 150, 200, 250, dan 300 ppm serta masing-masing konsentrasi dilakukan dengan tiga kali ulangan. Pengujian pada konsentrasi bervariasi ini ditunjukkan untuk melihat pengaruh penambahan konsentrasi ekstrak terhadap peningkatan daya inhibisi dan penurunan aktivitas lipase pankreas. Selain itu juga ditunjukkan untuk melihat besarnya daya inhibisi ekstrak pada serangkaian konsentrasi di bawah nilai toksisitasnya $\left(\mathrm{LC}_{50}\right)$ dan dilakukan pengamatan aktivitas lipase pankreas tanpa penambahan ekstrak (kontrol negatif) untuk melihat pengaruh inhibisi ekstrak tersebut terhadap aktivitas lipase pankreas. Aktivitas lipase pankreas dengan penambahan ekstrak dihitung dengan membandingkan nilai serapannya dengan serapan standar, yaitu asam oleat.

Pengaruh penambahan ekstrak air dan etanol $70 \%$ daun asam jawa pada berbagai konsentrasi ditunjukkan oleh Gambar 1. Berdasarkan semua ragam konsentrasi memiliki kemampuan sebagai inhibitor lipase pankreas, daya inhibisinya lebih besar dibandingkan dengan 
kontrol positif, dan peningkatan daya inhibisi lipase pankreas tidak berbanding lurus dengan peningkatan konsentrasi ekstrak. Artinya, peningkatan konsentrasi ekstrak yang ditambahkan tidak selalu meningkatkan daya inhibisinya.

Berdasarkan Gambar 1 dapat dilihat bahwa kontrol positif memiliki daya inhibisi sebesar $10,6 \%$ pada konsentrasi 100 ppm, ekstrak air daun asam jawa memiliki daya inhibisi yang terbesar pada konsentrasi 300 ppm sebesar 39,4\%, dan ekstrak etanol memiliki daya inhibisi terbesar pada konsentrasi 150 ppm sebesar 49,0\% (Gambar 1). Artinya, ekstrak air dan etanol daun asam jawa pada konsentrasi 300 dan 150 ppm mampu menghambat akivitas enzim lipase pankreas untuk menghidrolisis asam oleat sebesar 39,4 dan $49,0 \%$. Ekstrak etanol daun asam jawa memiliki daya inhibisi yang paling tinggi dibandingkan dengan ekstrak air daun asam jawa dan kontrol positif terhadap aktivitas lipase pankreas manusia. Hal ini disebabkan oleh jumlah kandungan senyawa metabolit sekunder yang dimiliki oleh ekstrak etanol lebih banyak dibandingkan dengan ekstrak air daun asam jawa. Hasil ini senada dengan penelitian yang dilakukan oleh Han et al., (1999) dan Rahardjo et al., (2005) menyatakan bahwa ekstrak air tanaman teh oolong dan ekstrak etanol daun jati belanda dapat menghambat aktivitas lipase. Hal ini senada juga dengan Silitonga (2008) yang menyatakan bahwa ekstrak etanol daun jati belanda dan rimpang bangle memiliki daya inhibisi lebih besar dibandingkan dengan ekstrak air. Hal ini sama dengan kemampuan ekstrak etanol CT-II dari buah Cassia nomame yang menunjukkan bahwa ekstrak etanol dari buah tersebut mampu menghambat aktivitas lipase pankreas porsin secara in vitro pada konsentrasi 0.07 sampai dengan $0.1 \mathrm{mg} / \mathrm{ml}$ dengan daya inhibisi sebesar $50 \%$ dan triolein sebagai substrat, serta pengaruh antiobesitas pada tikus yang mempunyai

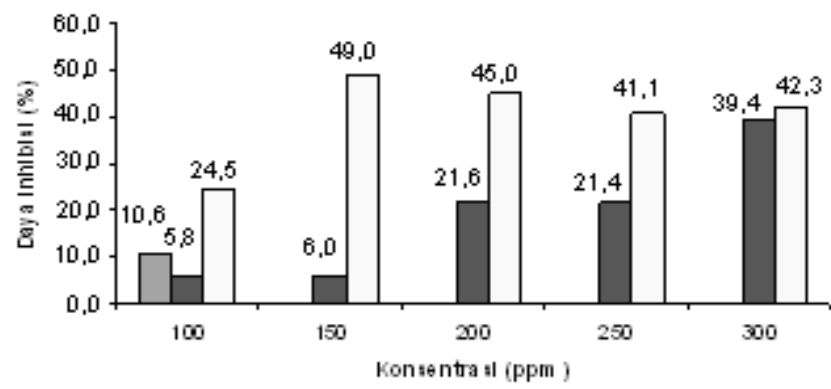

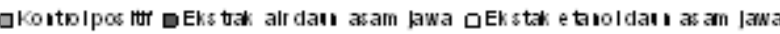

Gambar 1. Daya inhibisi kontrol positif, ekstrak air, dan ekstrak etanol daun asam jawa terhadapaktivitas lipase pankreas lemak yang tinggi secara in vivo, sehingga dapat digunakan sebagai zat tambahan untuk pencegahan obesitas dan hipertrigliseridemia pada manusia (Yamamoto et al., 2000).

Hasil pengujian ekstrak rimpang kunci pepet terhadap aktivitas lipase pankreas terlihat pada Gambar 2. Berdasarkan Gambar 2 terlihat bahwa tidak semua ragam konsentrasi ekstrak etanol rimpang kunci pepet memiliki kemampuan sebagai inhibitor lipase pankreas, sedangkan semua ragam konsentrasi ekstrak air rimpang kunci pepet memiliki kemampuan sebagai inhibitor lipase pankreas. Daya inhibisi ekstrak air dan etanol rimpang kunci pepet pada konsentrasi 100 ppm lebih besar dibandingkan dengan kontrol positif.

Ekstrak air rimpang kunci pepet memiliki daya inhibisi maksimum pada konsentrasi 200 ppm dengan daya inhibisi sebesar $65,1 \%$ dan ekstrak etanol pada konsentrasi 250 ppm dengan daya inhibisi sebesar $36,5 \%$. Ekstrak etanol rimpang kunci pepet pada konsentrasi 200 dan 300 ppm memiliki daya inhibisi bernilai negatif dan aktivitas lipase pankreas meningkat. Hal ini diduga ekstrak yang digunakan masih berupa ekstrak kasar yang belum murni karena masih berupa gabungan dari beberapa golongan senyawa yang kemungkinan memiliki respon yang berbeda atau bahkan bersifat antagonis satu sama lain dalam menghambat aktivitas lipase pankreas pada konsentrasi tertentu.

Berdasarkan hasil tersebut terlihat bahwa ekstrak air memiliki daya inhibisi yang paling tinggi dibandingkan dengan ekstrak etanol. Walaupun dari hasil uji fitokimia menunjukkan bahwa ekstrak etanol rimpang kunci pepet lebih banyak mengandung senyawa metabolit sekunder. Hasil ini didukung oleh penelitian Han et al., (1999) yang menyatakan bahwa ekstrak air teh oolong dapat menghambat aktivitas

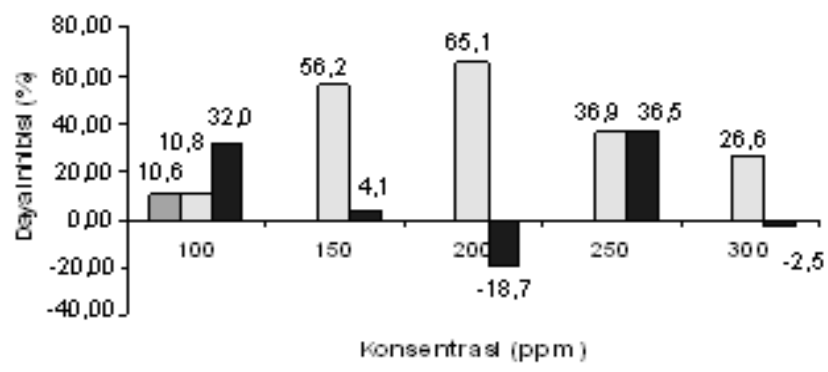

口Kontrol pos Itlf םEkstrak alr kuncl pepet a Ekstrak etanol kuncl pepet Gambar 2. Daya inhibisi kontrol positif, ekstrak air, dan etanol rimpang kunci pepet terhadap aktivitas lipase pankreas 
lipase pankreas pada konsentrasi 500-2000 ìg/ml dan senyawa kafein diidentifikasi sebagai aktivator noradrenalin yang menyebabkan lipolisis. Lee et al., (2005) menyatakan bahwa senyawa krosetin dan krosin yang diisolasi dari ekstrak air Gardenia fructus berpotensi sebagai inhibitor lipase pankreas secara in vitro dengan nilai $I C_{50}$ sebesar 2,1 dan $2,7 \mathrm{mg} / \mathrm{ml}$ (triolein sebagai substrat), krosin dan krosetin juga berpotensi dalam aktivitas hipolipidemik (antiobesitas) pada Triton WR-133 atau minyak jagung yang diberikan pada tikus yang mempunyai lemak tinggi secara in vivo.

Daya inhibisi tertinggi ekstrak etanol kedua tanaman melebihi daya inhibisi tertinggi ekstrak etanol beberapa tanaman lainnya terhadap aktivitas lipase, seperti ekstrak etanol daun jati belanda, yaitu 25,3\% pada konsentrasi 60 ppm dan rimpang bangle sebesar 29,2\% pada konsentrasi 100 ppm (Silitonga 2008), serta daun kemuning sebesar 22,8\% pada konsentrasi 30 ppm (Martatilofa 2008). Daya inhibisi ekstrak etanol lebih besar pada daun asam jawa karena pada ekstrak etanol lebih banyak senyawa yang terekstrak dan senyawa tersebut dapat menghambat aktivitas lipase pankreas, sehingga meningkatkan pengaruh penghambatan terhadap enzim tersebut, sedangkan ekstrak air pada rimpang kunci pepet mempunyai daya inhibisi yang paling besar dibandingkan dengan ekstrak etanol.

Senyawa-senyawa yang diperkirakan dapat menghambat aktivitas lipase pankreas pada ekstrak air dan ekstrak etanol daun asam jawa, yaitu flavonoid, saponin, steroid, dan tanin. Senyawa yang diduga dapat menghambat aktivitas lipase pankreas pada ekstrak air rimpang kunci pepet, yaitu flavonoid, tanin, dan saponin, sedangkan senyawa yang diduga dapat menghambat aktivitas ekstrak etanol rimpang kunci pepet, yaitu flavonoid, saponin, dan triterpenoid. Senyawa flavonoid terbukti dapat meng-hambat aktivitas lipase secara in vitro, di antaranya yaitu yang terdapat pada rimpang bangle (Iswantini et al., 2003) dan galangal (Shin et al., 2003). Saponin juga terbukti dapat menghambat aktivitas lipase baik secara in vitro maupun in vivo.

Selain itu, senyawa tanin pada ekstrak tanin rimpang bangle juga memiliki potensi dalam menghambat aktivitas lipase (Iswantini et al., 2003). Senyawa triterpenoid yang terdapat pada ekstrak etanol rimpang kunci pepet dapat menghambat aktivitas lipase pankreas. Hal ini senada dengan Xu et al., (2005) yang menyatakan bahwa senyawa triterpenoid pada Platycodi radix yang mengandung senyawa platikodin A, C, D, dan deaploplatikodin D diketahui dapat menghambat aktivitas lipase pankreas pada konsentrasi $500 \mathrm{ig} / \mathrm{ml}$ dengan daya inhibisi sebesar 3.3; 5.2; 34.8, dan $11,7 \%$. Adanya senyawa alkaloid pada ekstrak etanol rimpang kunci pepet diduga mengakibatkan adanya peningkatan aktivitas lipase pankreas sehingga daya inhibisinya menurun, akan tetapi belum ada literatur yang mengatakan bahwa senyawa alkaloid mampu meningkatkan aktivitas lipase pankreas. Oleh karena itu, adanya alkaloid akan memberikan pengaruh yang berlawanan dan mengakibatkan daya inhibisi ekstrak menurun, sedangkan adanya flavonoid, saponin, dan tanin akan memberikan pengaruh yang sinergis dan mengakibatkan daya inhibisi ekstrak meningkat.

Tabel 2 memuat data daya inhibisi maksimum tiap ekstrak tanaman, kontrol negatif (tanpa penambahan ekstrak), dan kontrol positif (dengan penambahan Xenica $\left.{ }^{\circledR}\right)$. Berdasarkan data tersebut terlihat bahwa semua ekstrak tanaman mempunyai daya inhibisi lebih besar dibandingkan dengan daya inhibisi Xenical ${ }^{\circledR}$ sebagai kontrol positif. Ekstrak air rimpang kunci pepet paling berpotensi dalam menghambat aktivitas lipase pankreas dibandingkan dengan yang lainnya karena daya inhibisinya lebih dari 50\%. Ekstrak air rimpang kunci pepet dapat menurunkan aktivitas enzim dari $2,11 \times 10^{4} \mu \mathrm{mol} / \mathrm{l}$.menit menjadi $1,68 \times 10^{4} \mu \mathrm{mol} / \mathrm{l}$.menit pada konsentrasi 200 ppm.

Krosin dan krosetin dapat menghambat biosintesis trigliserida sebagaimana halnya kolesterol dan absorpsinya dari intestin dalam darah. Krosin dan krosetin berpotensi sebagai inhibitor pada dosis $50 \mathrm{mg} / \mathrm{kg}$, sedangkan Xenical ${ }^{\circledR}$ pada dosis $10 \mathrm{mg} / \mathrm{kg}$. Jika memperhatikan data tersebut, maka hasil penelitian kali ini membuktikan bahwa ekstrak daun asam jawa dan rimpang kunci pepet memiliki pengaruh yang lebih besar terhadap penghambatan aktivitas lipase

Tabel 2. Daya inhibisi maksimum kontrol negatif, kontrol positif, dan ekstrak tanaman

\begin{tabular}{lcc}
\hline \multicolumn{1}{c}{ Ekstrak } & $\begin{array}{c}\text { Konsentrasi } \\
(\mathrm{ppm})\end{array}$ & $\begin{array}{c}\text { Daya } \\
\text { Inhibisi (\%) }\end{array}$ \\
\hline Kontrol (-) & 0 & 0,0 \\
Air daun asam jawa & 300 & 39,4 \\
Etanol daun asam jawa & 150 & 49,0 \\
Air rimpang kunci pepet & 200 & 65,1 \\
Etanol rimpang kunci pepet & 250 & 36,5 \\
Kontrol (+) & 100 & 10,6 \\
\hline
\end{tabular}


pankreas, sehingga sangat memungkinkan untuk digunakan sebagai obat antiobesitas.

Kontrol positif yang digunakan, yaitu Xenical ${ }^{\circledR}$ yang mengandung zat aktif berupa orlistat (tetrahidrolipstatin). Xenical ${ }^{\circledR}$ digunakan sebagai kontrol positif, yaitu untuk membandingkan mekanisme antara sampel dengan kontrol positif terhadap lipase pankreas, tetapi pada penelitian ini mekanisme sampel terhadap lipase pankreas tidak diketahui karena tidak dilakukan penelitian yang lebih lanjut mengenai mekanisme sampel terhadap lipase pankreas.

Berdasarkan Gambar 3 dapat terlihat bahwa daya inhibisi terbesar kontrol positif $\left(\right.$ Xenical $^{\circledR}$ ) sebesar $10.6 \%$ pada konsentrasi 100 ppm, sedangkan pada konsentrasi 150 sampai dengan 300 ppm daya inhibisinya bernilai negatif. Artinya, kontrol positif (Xenica $^{\circledR}$ ) bekerja maksimum dalam menghambat aktivitas lipase pankreas pada konsentrasi 100 ppm. Nilai daya inhibisi Xenical ${ }^{\circledR}$ tersebut berbeda dengan yang dikemukakan oleh Silitonga (2008) dengan konsentrasi yang sama, yaitu sebesar 17,5\%. Hal ini dapat disebabkan oleh konsentrasi substrat yang digunakan berbeda, yaitu $16,7 \mu \mathrm{g} / \mu \mathrm{l}$ dan pada waktu dilarutkan Xenica ${ }^{\circledR}$ tidak larut sempurna dengan bufer fosfat $\mathrm{pH} 8$ karena Xenical ${ }^{\circledR}$ lebih larut dalam etanol dan metanol (Roche 2008a). Akan tetapi, hasil ini tidak senada dengan Hadvary et al., (1988). Hadvary et al., (1988) menyatakan bahwa orlistat mampu menghambat lipase pankreas hingga $50 \%$ pada konsentrasi $0,1 \mu \mathrm{g} / \mathrm{ml}$ secara in vitro dan $0.3 \mu \mathrm{g} / \mathrm{ml}$ secara in vivo pada cairan usus tikus. Xenical ${ }^{\circledR}$ yang digunakan sebagai kontrol positif pada penelitian ini tidak berupa orlistat murni. Metode dan bahan-bahan yang digunakan pun berbeda. Hadvary et al., (1988) menggunakan substrat triolein murni, bufer Tris/ $\mathrm{HCl}, \mathrm{NaCl}, \mathrm{CaCl}_{2}$, dimetil sulfoksida pada suhu ruang, dan waktu inkubasi 10 menit.

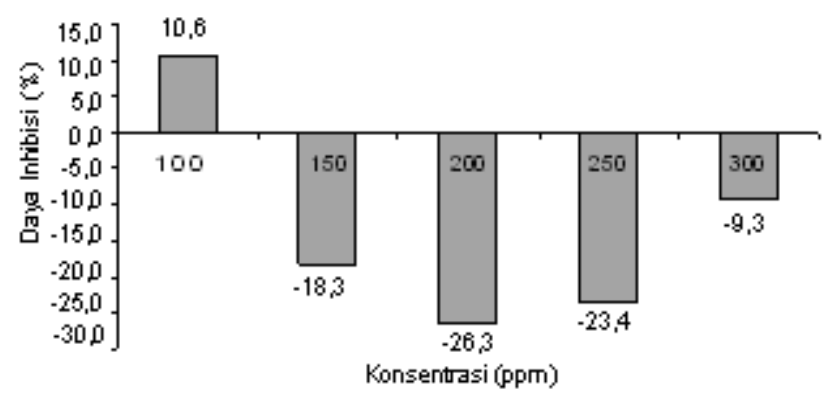

Gambar 3. Daya inhibisi kontrol positif $\left(\right.$ Xenical $\left.^{\circledR}\right)$ pada berbaga konsentrasi terhadap aktivitas lipase pankreas
Perbedaan metode uji inhibisi, substrat, dan waktu inkubasi akan sangat mempengaruhi nilai daya inhibisi yang diperoleh dari setiap percobaan. Metode yang digunakan pada penelitian ini dapat dikatakan lebih efektif karena dengan menggunakan substrat dan pereaksi-pereaksi lain yang lebih murah dan sederhana telah dapat memperlihatkan kemampuan inhibisi ekstrak-ekstrak contoh terhadap aktivitas lipase pankreas. Selain itu, kandungan substrat yang diginakan dalam penelitian ini (minyak wijen) tidak mengandung asam linoleat (Arslan et al., 2007) sedangkan triolein mengandung asam linoleat sebesar $60 \%$ (Botelho et al., 2009), jadi perbedaan kandungan yang cukup signifikan inilah yang mungkin menyebabkan perbedaan hasil daya inhibisi ekstraekstrak yang diujikan.

Uji Statistik. Berdasarkan data yang diperoleh kemudian dilakukan uji statistik, yaitu uji beda perlakuan menggunakan uji Duncan dengan rancangan acak lengkap. Uji ini dilakukan untuk menguji apakah tiap perlakuan memiliki perbedaan yang nyata dalam menghambat aktivitas lipase pankreas (Hanafiah, 2005). Perlakuan yang dibandingkan adalah ekstrak air dan etanol pada daya inhibisi maksimum dari kedua tanaman, serta perlakuan dengan kontrol negatif dan kontrol positif. Berdasarkan perhitungan yang telah dilakukan terlihat bahwa daya inhibisi ekstrak etanol dari daun asam jawa dan rimpang kunci pepet tidak berbeda nyata karena daya inhibisi kedua tanaman tersebut tidak berbeda jauh. Untuk ekstrak air, daya inhibisi dari kedua tanaman ini berbeda nyata. Hal ini disebabkan oleh nilai daya inhibisi ekstrak air rimpang kunci pepet yang jauh lebih besar dibandingkan dengan ekstrak air daun asam jawa.

Uji beda perlakuan terhadap hasil inhibisi terbaik, yaitu ekstrak etanol daun asam jawa, ekstrak air rimpang kunci pepet, kontrol negatif, dan kontrol positif menyatakan bahwa semua perlakuan memberikan pengaruh daya inhibisi yang berbeda nyata. Perlakuan tersebut, yaitu ekstrak etanol daun asam jawa dengan kontrol negatif, ekstrak air rimpang kunci pepet dengan kontrol negatif, ekstrak etanol daun asam jawa dengan kontrol positif, ekstrak air rimpang kunci pepet dengan kontrol positif, ekstrak etanol daun asam jawa dengan ekstrak air rimpang kunci pepet, dan kontrol negatif dengan kontrol positif. 
Kadar Flavonoid Total. Metode ini berdasarkan pada Codex (1986) diacu dalam Nobre et al., (2005) dengan beberapa modifikasi, yaitu sistem hidrolisis yang berupa $1,0 \mathrm{ml}$ urotropin 0,5\% dan $2 \mathrm{ml}$ asam hidroklorat diganti dengan Iarutan heksametilenatetramina $0,5 \%$ (b/v) dalam metanol dan $2 \mathrm{ml} \mathrm{HCl} 25 \%$, serta panjang gelombang yang digunakan dari $425 \mathrm{~nm}$ diganti dengan $370,8 \mathrm{~nm}$. Kadar flavonoid dan senyawa fenolik lain di dalam tanaman berbeda-beda di antara setiap bagian, jaringan, dan umur tanaman, serta dipengaruhi oleh faktor-faktor lingkungan. Faktor-faktor yang mempengaruhi, yaitu temperatur, sinar UV, sinar tampak, nutrisi, ketersediaan air, dan kadar $\mathrm{CO}_{2}$ pada atmosfer. Oleh karena itu, pada penelitian ini perlu dilakukan penentuan kadar flavonoid total pada ekstrak yang memiliki daya inhibisi terbesar. Ekstrak yang dinalisis kadar flavonoid totalnya, yaitu ekstrak etanol daun asam jawa dan ekstrak air rimpang kunci pepet. Metode analisis yang biasa digunakan untuk menentukan kadar flavonoid dalam simplisia tanaman obat, yaitu dengan spektrofotometri UV (Codex 1986 diacu dalam Nobre et al., 2005), kromatografi cair kinerja tinggi (KCKT) (Merken \& Beecher, 2000), dan elektroforesis kapiler (Marchart et al., 2003). Metode-metode tersebut melibatkan serangkaian tahapan yang membutuhkan waktu yang lama dalam pelaksanaannya. Metode lain yang dapat digunakan untuk menentukan kadar flavonoid, yaitu teknik infra red (IR) yang digabungkan dengan kemometrik. Pada penelitian ini metode yang digunakan, yaitu metode Codex (1986) diacu dalam Nobre et al., (2005) disebut juga metode $\mathrm{AlCl}_{3}$.

Analisis kadar flavonoid total diawali dengan memilih sampel yang memiliki daya inhibisi terbesar. Setelah didapatkan ekstrak sampel yang memiliki daya inhibisi terbesar, maka dilakukan analisis kadar flavonoid total. Rendemen ekstrak etanol daun asam jawa dan ekstrak etanol rimpang kunci pepet yang diperoleh adalah 12,2 dan $19,2 \%$ (b/b). Berdasarkan metode analisis Chang et al., (2002), flavonoid total yang terukur termasuk dari golongan flavon dan flavonol yang terdapat pada ekstrak karena kedua golongan ini yang dapat membentuk kompleks stabil dengan $\mathrm{AlCl}_{3}$.

Kadar flavonoid total dihitung berdasarkan kurva standar kuersetin sehingga diperoleh persamaan regresi linear, yaitu $y=0,1064 x+0,0245$ dengan $R^{2}=0,9932$ yang selanjutnya akan digunakan untuk menghitung konsentrasi flavonoid dan kadar flavonoid total.
Berdasarkan hasil percobaan, konsentrasi flavonoid ekstrak etanol daun asam jawa dan ekstrak air rimpang kunci pepet berturut-turut sebesar 0,40 dan 0,024 ppm, sedangkan kadar flavonoid total dari ekstrak etanol daun asam jawa dan ekstrak air rimpang kunci pepet berturutturut sebesar 0,03 dan 0,02 × 10-2\% (b/b).

Day dan Underwood (2001) mengemukakan bahwa hasil analisis kuantitatif perolehan analit dapat digolongkan menjadi 3 kelompok, yaitu analit yang merupakan konstituen utama, konstituen minor, dan konstituen jejak atau runut. Analisis kuantitatif flavonoid pada ekstrak etanol daun asam jawa menunjukkan keberadaan flavonoid sebagai konstituen minor karena kadar yang diperoleh berada di antara 0,01-1\%, sedangkan ekstrak air rimpang kunci pepet menunjukkan keberadaan flavonoid sebagai konstituen jejak atau runut karena kadar yang diperoleh kurang dari $0,01 \%$.

\section{KESIMPULAN}

Ekstrak air dan etanol daun asam jawa dan rimpang kunci pepet berpotensi sebagai antiobesitas karena mampu menghambat aktivitas lipase pankreas secara in vitro. Ekstrak air rimpang kunci pepet memiliki daya inhibisi tertinggi dari semua ekstrak, yaitu sebesar $65,1 \%$ pada konsentrasi 200 ppm. Daya inhibisi yang dimiliki oleh ekstrak etanol daun asam jawa, ekstrak air rimpang kunci pepet, kontrol negatif, dan kontrol positif secara statistik berbeda nyata. Ekstrak etanol daun asam jawa memiliki kadar flavonoid dengan konstituen minor, sedangkan ekstrak air rimpang kunci pepet memiliki kadar flavonoid dengan konstituen jejak atau runut.

\section{UCAPAN TERIMA KASIH}

Kami ucapkan terima kasih kepada Direktorat Jenderal Pendidikan Tinggi Departemen Pendidikan Nasional yang telah mendanai penelitian ini melalui program Hibah Kompetensi Nomor: 219/SP2H/PP/ DP2M/V/2009, tanggal 30 Mei 2009 atas nama Dr. Dyah Iswantini Pradono, M. Agr.

\section{DAFTAR PUSTAKA}

Arslan, C., Uzun, B., Ulger, S. \& Cagirgan, MI. 2007. Determination of Oil Content and Fatty Acid Composition of Sesame Mutants Suited for Intensive Management Conditions. Euphytica 34:193-199.

Botelho, A.P., Santos-Zago, L.F. \& Costa de Oliveira A. 2009. Effect of conjugated linoleic acid supplementation on lipoprotein lipase activity in 3T3-L1 adipocyte culture, Rev. Nutr 22(5): 767-771. 
Chang, C.C., Yang, M.H. \& Wen, H.M. \& Chern, J.C. 2002 Estimation of total flavonoids content in propolis by two complementary colorimetric methods. Journal Food Drug Anal 10: $178-182$

Darusman, L.K., Rohaeti, E. \& Sulistiyani. 2001. Kajian senyawa golongan flavonoid asal tanaman bangle sebagai senyawa peluruh lemak melalui aktivitas lipase. Bogor: Pusat Studi Biofarmaka Lembaga Penelitian, IPB.

Desnuelle, P. \& Savary, P. 1963. Specifities of lipases. Journal Lipid Res 4: 369-384.

Digest Otc. 2006. Memilih obat pelangsing. http://sehat bugar. multiply.com/journal. Html (29 Des 2008).

Doughari, J.H. 2006. Antimicrobial activity of Tamarindus indica Linn. Tropical Journal Pharmaceu Res 5(2): 597-603.

Febriany, S. 2004. Potensi ekstrak tunggal bangle dan gabungannya dalam meningkatkan aktivitas enzim lipase secara in vitro. Skripsi Jurusan Kimia, FMIPA. Bogor: IPB.

Hadvary, P., Lengsfeld, H. \& Wolfer, H. 1988. Inhibition of pancreatic lipase in vitro by the covalent inhibitor tetrahydroplastin. Journal Biochem 256: 357-361.

Han, L.K., Takaku, T., Li, J., Kimura, Y. \& Okuda, H. 1999. Anti-obesity action of oolong tea. Int Journal Obesity 23: 98-105.

Han, L.K et al. 2001. Anti-obesity effects in rodents of dietary teasaponin, a lipase inhibitor. Int Journal Obesity 25: 14591464.

Han, L.K., Zheng, N.Y., Yoshikawa, M., Okuda, H. \& Kimura, Y. 2005. Anti-obesity effects of chikusetsusaponins isolated from Panax japonicus rhizomes. BioMed Central 5: 1-10.

Han, L.K et al. 2006. Reduction of fat storage in mice fed a highfat diet long term by treatment with saponins prepared from Kochia scoparia fruit. Phytother Res 20: 877-882.

Iswantini, D., Darusman, L.K., Gunawan, E. \& Nurulita, Y. 2003. Identifikasi senyawa bioaktif daun jati belanda (Guazuma ulmifolia Lamk.) sebagai pelangsing dengan menggunakan metode enzimatis (enzim lipase). Jurnal IImiah Pertanian Gakuryoku 9: 138-142.

Iswantini. D., Darusman, L.K, Febriany, S. 2004. Pengaruh ekstrak tunggal dan gabungan dari bangle terhadap aktivitas enzim lipase dalam kajian sebagai pelangsing. Di dalam: Tanaman Obat Indonesia XXIV. Prosiding Seminar dan Pameran Nasional; Bogor, 19-20 September 2003. Bogor: Pusat Studi Biofarmaka Lembaga Penelitian Institut Pertanian Bogor. hlm 276-283.

Joshita, D., Azizahwati. \& Wahyuditomo. 2000. Pengaruh daun jati belanda terhadap kerja enzim lipase secara in vitro. Warta Tumbuhan Obat Indonesia 6(2): 16-22.
Lee, I.A., Lee, J.A., Baek, N.I. \& Kim, D.H. 2005 Antihiperlipidemic effect of crocin isolated from the fructus of Gardenia jasminoides and its metabolite crocetin. Biol Pharm Bull 28(11): 2106-2110.

Li, F., Li, W., Fu, H., Zhang, Q. \& Koike K. 2007. Pancreatic lipase-inhibiting triterpenoid saponin from fruit of Acanthopanax senticosus. Chem Pharm Bull 55(7): 10871089.

Marchart, E., Krenn, L. \& Kopp, B. 2003. Quantificication of the flavonoid glycosides in Passiflora incarnata by capillary electrophoresis. Planta Med 69: 452-456.

Martatilofa, E. 2008. Daya inhibisi ekstrak bangle, jati balanda, kemuning, dan formula biolangsing terhadap lipase pancreas. Skripsi Jurusan Kimia, FMIPA. Bogor: IPB.

Merken, H.M. \& Beecher, G.R. 2000. Liquid chromatographic method for the separation and quantification of prominent flavonoid aglycones. Journal Chromatogr A 897: 177-184.

Meyer et al. 1982. Brine shrimp: A convient general bioassay for active plant constituents. Planta Medica 45: 31-34

Nobre, C.P., Raffin, F.N. \& Moura, T.F. 2005. Standardization of extracts from Momordica charantia L. (Cucurbitaceae) by total flavonoids content determination. Acta Farm. Bonaerense 24(4): 562-566.

Rahardjo, S.S. 2004. Pengaruh ekstrak etanol daun jati belanda (Guazuma ulmifolia Lamk.) terhadap aktivitas enzim lipase serum Rattus norvegicus. Tesis Pasca Sarjana. Yogyakarta: UGM.

Roche. 2008a. Xenical ${ }^{\circledR}$ (Orlistat). [terhubung berkala]. http:// www. roche. co.id/bahasa/index.html (7 Des 2008).

Shin, J.E, Han, M.J. \& Kim, D.H. 2003. 3-Methylethergalangin isolated from Alpinia officinarum inhibits pancreatic lipase. Biol Pharm Bull 26(6): 854-857.

Silitonga, R.F. 2008. Daya inhibisi ekstrak daun jati belanda dan bangle terhadap ativitas lipase pankreas sebagai antiobesitas. Skripsi Jurusan Kimia, FMIPA. Bogor: IPB.

Wirakusumah, L.H. 2005. Fraksinasi dan karakterisasi senyawa aktif flavonoid dari ekstrak kasar metanol rimpang Bangle (Zingiber cassumar Roxb.). Skripsi Jurusan Kimia, FMIPA. Bogor:IPB.

Xu, B.J., Han, L.K., Zheng, Y.N, Lee, J.H. \& Sung, C.K. 2005. In vitro inhibitory effect of triterpenoidal saponins from Platycodi radix on pancreatic lipase. Arch Pharm Res 28(2): 180-185.

Yamamoto, M et al. 2000. Anti-obesity effects of lipase inhibitor CT-II. An extract from edible herbs, Nomame Herba, on rats fed a high-fat diet. Int Journal Obesity 24: 758-764. 